\title{
'International Meaning': Comity in Fundamental Rights Adjudication
}

(2002) 13 International Journal of Refugee Studies 280-292.

\begin{abstract}
In fundamental rights adjudication, should judges defer to the judgment of other decision makers? How can they defer, without betraying the respect that judges ought to accord those rights? How can they refuse to defer, without betraying the respect that judges ought to accord to other decision makers? I argue that only principles of comity (such as the principles of subsidiarity in the Strasbourg Court and justiciability in the British courts) justify deference, and their reach is limited. Comity never forbids the judges to take and to act upon a different view of fundamental rights from that of another decision maker. I elaborate this view by reference to the decision of the House of Lords in Adan and Aitseguer [2001] 1 All ER 593.
\end{abstract}

\section{Timothy Endicott* Balliol College, Oxford}

Fundamental rights (rights such as the right not to be persecuted or tortured or killed on account of your religion or race or clan) are to be respected and protected.

It is easy to agree with that claim, but every aspect of it raises difficult questions for lawyers and politicians and philosophers. What rights (besides those I have mentioned) are fundamental? Why? Can they be outweighed? Which people and agencies are responsible for protecting them, and how? How should those people and agencies deal with each other?

Of all these questions, I will address only the last. I will call it the problem of comity. It is a problem of special legal importance. Some aspects of it have been widely debated-especially the question of how and when judges ought to defer to legislatures. But the question has many other important aspects which have not had as much attention as they deserve.

The courts in Britain were already familiar with questions of comity, but they have been addressing them in a new way since the Human Rights Act came into force in October 2000. That Act incorporates the European Convention on Human Rights into British law in a peculiar way. In the first part of this lecture I would like to introduce you to the changes that have already come about in the first seven months of the Act. I want to do so not only to bring you news from a frontier of litigation over fundamental rights; I want to mention the Human Rights Act especially because it gives a new urgency to the main topic of my lecture.

\footnotetext{
* A lecture given at the conference on "New Perspectives on Human Rights" at the Universidad Complutense de Madrid, 21 May 2001. I am grateful to Professor Maria Jose Falcon for inviting me to speak. This lecture will be published in Spanish translation in the proceedings of the conference, "Nuevas perspectivas de los derechos humanos", Kluwer, 2002.
} 
I think that it is important to see that all questions of judicial protection of fundamental rights raise questions of comity. My lecture aims to identify some principles of comity that ought to inform judicial action, not only in Britain under the Human Rights Act, but generally. The quickly developing situation in the United Kingdom serves to highlight the importance of the problem of comity, because of the new challenges that the Human Rights Act raises.

\section{The Human Rights Act}

The Human Rights Act gives effect to the European Convention on Human Rights in British law, but does not make it supreme law. The British did not want judges to be able to quash statutes as unlawful in the way that judges do in Canada and the United States. Instead, the Act provides three new techniques for the protection of Convention rights:

It requires courts and other public authorities to interpret statutes 'so far as possible' to accord with the European Convention on Human Rights (s.3).

It makes it unlawful for a public authority to act incompatibly with a Convention right, unless required to do so by statute (s.6).

It gives judges power to issue a declaration that a statute is incompatible with a Convention right (s.4). A declaration of incompatibility does not invalidate a statute or affect its operation, but it triggers a special fast-track power for the government to remedy the incompatibility without the ordinary legislative process.

Will these techniques revolutionize British law? They have already had a significant impact on some areas: the courts have struck down a system for appointment of temporary judges in Scotland, on grounds of incompatibility with the right to an independent tribunal in Article 6 of the Convention. ${ }^{1}$ And the Mental Health Act has been held to be incompatible with the right to liberty in Article 5 of the Convention, because it puts the the burden of proof on a patient detained because of a mental disorder to satisfy the mental health review tribunal that he is entitled to be discharged. ${ }^{2}$ Aside from these specific effects, the courts have suggested wider extensions of the effect of the Act. When Michael Douglas and Catherine Zeta-Jones recently sued Hello! magazine for infringing their privacy by publishing unauthorized photos of their wedding, the Court of Appeal gave a form of horizontal effect to Article 8 of the Convention. As Lord Justice Keene put it, the court's obligation to act in a way that is compatible with Convention rights

\footnotetext{
${ }^{1}$ Starrs v Procurator Fiscal, [2000] HRLR 191 (High Court of Justiciary). That case was decided in November 1999 under the Scotland Act 1998, which anticipated the Human Rights Act by making it unlawful for a member of the Scottish executive to act incompatibly with the Convention (s. 57(2)).

${ }^{2}$ R v Mental Health Review Tribunal et al, ex parte H, [2001] EWCA Civ 415, [2001] HRLR 36.
} 
'arguably includes their activity in interpreting and developing the common law, even where no public authority is a party to the litigation'. 3

So the consequences of the Act are far-reaching, and the form of argument is changing in all criminal procedure cases, many ordinary administrative law cases, and even tax cases, as lawyers seek out and argue Human Rights Act issues. But there are signs that the judges will not revolutionize British law wholesale, or take over the running of the country. The most dramatic use of the Human Rights Act so far was in February 2001, when a British court declared that the planning process in Britain was incompatible with Article 6 of the Convention, on the ground that the Secretary of State for the Environment had a role in determining applications for planning permission that prevented applicants from receiving an independent and impartial hearing. But in May the House of Lords overturned that decision, and its reasons suggest a cautious approach to fundamental rights adjudication. The House of Lords decided that 'In a democratic society, it is entirely appropriate that the determination of planning policy and its application in particular cases should be entrusted to an administrator such as the Secretary of State who was answerable to Parliament as regards policy aspects of his decision and to the High Court as regards the lawfulness and fairness of his decisionmaking process. ${ }^{4}$

The same approach is suggested in a recent Court of Appeal decision, which held that 'a court judicially reviewing decisions which involved human rights issues cannot substitute its own view for that of the executive. There are areas of judgment considered by democratically elected bodies or persons which necessarily command deference from the courts.' 5

These decisions make it clear that the British courts will defer to the executive and the legislature on questions of policy and of expediency. It may seem that judges protecting fundamental rights should show no such deference at all: after all, policy and expediency are no excuse for human rights abuses. But in fact I think that the British courts have started in the right way. The European Convention on Human Rights does not simply forbid torture and murder; it also provides civil and criminal process rights which can never be identified without asking questions of expediency. And it protects freedoms which the Convention itself states as subject to limits necessary in a democratic society in the interests of various public goals. To deal with those features of the Convention, the European Court of Human Rights in Strasbourg developed a 'margin of appreciation' doctrine, which recognizes the relative difficulty in an international court of assessing considerations of policy and expediency within a nation. As the Strasbourg Court put it in the Handyside case in 1976, 'State authorities are in principle in a better position than the international judge to give an opinion on the exact content' of the appropriate limitations on Convention entitlements. ${ }^{6}$

\footnotetext{
${ }^{3}$ Douglas v Hello! Ltd [2001] 2 WLR 992 (CA).

${ }^{4} R$. (on the application of Alconbury Developments Ltd) v Secretary of State for the Environment, Transport and the Regions, [2001] 2 WLR 1389, [2001] 2 All ER 929 (9 May, 2001).

${ }^{5} R$. v Secretary of State for the Home Department Ex parte Isiko, [2001] HRLR 15, [2001] Imm AR 291.

${ }^{6}$ Handyside (1979-80) 1 EHRR 737.
} 
That doctrine is founded on a principle of subsidiarity - a principle that does not apply to the British courts. But the recent cases show that the British courts too will allow the government a discretionary leeway founded on a principle of justiciability: where an administrative agency is better placed than a judge to make the decision in question, without abandoning the fundamental rights of people affected by the decision, the judges will defer to that agency.

The biggest challenge to the British courts - and the topic of my paper-is the question of the appropriate limits of deference to other decision makers. When a party to litigation argues that his or her fundamental rights are at stake, under what circumstances (if any) should judges defer to the judgment of other decision makers? How can they defer, without betraying the respect that judges ought to accord those rights? How can they refuse to defer, without betraying the respect that judges ought to accord to other decision makers?

My general answer to the question of the limits of deference (which I will try to explain and defend in the rest of my paper) is that a court should defer for reasons of comity. And the principles of subsidiarity in the Strasbourg Court and justiciability in the British courts are principles of comity. Only such principles justify deference, and their reach is limited. Comity never forbids the judges to take and to act upon a different view of fundamental rights from that of another decision maker. To explain this view, I will use recent British developments not in the law of the European Convention on Human Rights, but in another area that raises very pressing questions of comity: the law of the 1951 Geneva Convention on the Status of Refugees.

\section{'International Meaning': The Adan Case}

The parties to the Geneva Convention have undertaken not to send back people who have fled their home countries because of a well-founded fear of being persecuted for reasons of race, religion, nationality, membership of a social group, or political opinion. But not all European countries interpret this obligation in the same way. The German and French authorities have read it as protecting people from state persecution: an asylum seeker must show that the agent of the persecution is a state authority, or at least that state authorities are complicit in some way. Otherwise the asylum seeker is not considered to be a refugee. That is the 'accountability theory' of the Geneva Convention. In Britain, the courts have imposed on the government a different interpretation of the Geneva Convention: the 'protection theory'. On this view, it makes no difference who is engaging in persecution. If the state authorities in the asylum seeker's country are providing satisfactory protection from persecution, then of course there is no wellfounded fear of persecution. So the actions of state authorities matter, but it does not matter whether the state is complicit in the persecution. As the House of Lords put it, 'if for whatever reason the state in question is unable to afford protection against factions within the state, then the qualifications for refugee status are complete'?

This difference in interpretation has created a serious political and legal problem: many victims of persecution who escape to Germany and France have a reason to flee

\footnotetext{
${ }^{7}$ Adan v Secretary of State for the Home Department [1999] 1 AC 293, 306 per Lord Lloyd.
} 
again to a country like Britain - to escape an interpretation of the Geneva Convention according to which they do not count as refugees. In Britain, $80 \%$ of asylum seekers from Algeria are given asylum; in France, only 5\%. ${ }^{8}$ There are hundreds of asylum seekers in the United Kingdom who have fled from Germany and France because of this difference in interpretation.

One of them is a Somali woman called Lul Adan. She fled to Germany to escape persecution by a rival clan; then she fled to Britain to escape the German interpretation of the Geneva Convention. The British government tried to send her back to Germany, and her case went to the House of Lords, resulting in a remarkable decision on comity in the protection of fundamental rights. ${ }^{9}$

Parliament gave the government power to send an asylum seeker to a third country, as long as the government of that country will not send her to another country 'otherwise than in accordance with the Convention'. ${ }^{10}$ Ms.Adan said that Germany would send her back to Somalia otherwise than in accordance with the Geneva Convention, because the persecution was not connected with the Somali state: the rival clan was not a state authority, and no state authority was complicit in the persecution. In fact, there was no state authority in Somalia.

The British government said that Germany does comply with the Geneva Convention: we in Britain have our interpretation, and the Germans have theirs. The fact that they do not agree with us does not mean that they are ignoring their obligations under the Geneva Convention. So, the government said, Germany would not send her back to Somalia 'otherwise than in accordance with the Convention'.

In previous decisions, the Court of Appeal had held that, before a third country can be held not to be safe, 'the third country's approach would have to be outside the range of tolerance which one signatory country, as a matter of comity, is expected to extend to another.' 11 The court had held that there was a margin of appreciation in the interpretation of the Geneva Convention. So it seemed that the government had a good argument in the Adan case: in English law, comity requires that the courts should not view Germany as an unsafe third country merely because its interpretation of the Geneva Convention is different from the British interpretation. The courts should only do so if the German approach is outside the range of tolerable interpretations of the Geneva Convention.

The House of Lords rejected that view. The judges held that the Geneva Convention has an 'international meaning'. Rather than taking colour from local

\footnotetext{
${ }^{8}$ See $R$ v Secretary of State for the Home Department, ex parte Adan and Aitseguer [2001] 1 All ER 593 at 616.

${ }^{9} R v$ Secretary of State for the Home Department ex parte Adan and Aitseguer [2001] 1

All E R 593. The Adan in this case is a different person from the Adan in the earlier case (note 7). Aitseguer fled from Algeria to France to escape persecution by the Groupe Armee Islamique. He travelled on to Britain to escape the French interpretation of the Geneva Convention, according to which he was not a refugee because the Algerian government was not involved in the persecution.

${ }^{10}$ Asylum and Immigration Act 1996 s.2(2)(c).

${ }^{11}$ Kerrouche v Secretary of State for the Home Department [1997] Imm AR 610 per Lord Woolf.
} 
conditions in the country that the asylum seeker first flees to, the meaning of the Geneva Convention is 'autonomous'. 'In principle, there can only be one true interpretation of a treaty' - an interpretation which explicates the 'true autonomous and international meaning of the treaty. And there can only be one true meaning. ${ }^{13}$ That one meaning, according to the House of Lords, includes the protection theory, and rules out the accountability theory. So in British law, the government could not send Ms.Adan back to Germany: Germany would send her back to Somalia otherwise than in accordance with the Geneva Convention.

Was that decision right? Does it abandon the notion of comity, and amount to a discourteous criticism of Germany (and France) as countries that (1) fail to respect fundamental rights and (2) fail to fulfil their obligations in international law?

The Law Lords were concerned about this argument, but decided that they had to apply British law: Lord Steyn simply added 'I certainly intend no criticism of the interpretations adopted in good faith in Germany and France. ${ }^{14}$ Lord Hutton said that the Home Secretary's argument about comity was 'of little weight' because the court's task was to decide whether the Home Secretary had acted lawfully and 'not to pass judgment on the validity of a decision of a French or German court'. ${ }^{15}$ Similarly, Lord Hobhouse said that 'The question is not one of comity', ${ }^{16}$ but of deciding what English law requires of the Home Secretary. Lord Slynn said that the decision was 'not in any way contrary to the comity of nations or offensive to other states who interpret it differently and it does not begin to suggest malafides on their part. ${ }^{, 17}$

I think, with respect, that the judges were right that comity did not require a margin of appreciation in interpreting the Geneva Convention. But why not? Why isn't the House of Lords' decision insulting and offensive to the French and German authorities? After all, the decision says that those countries send refugees back to face persecution, contrary to the Geneva Convention. We will have a better understanding of comity in the protection of fundamental rights if we can see why it was right for the House of Lords to decide the case as it did, and why the decision was not a breach of comity.

\section{Comity: The Judicial Model}

What does comity require? Consider the model of comity among judges in a common law appellate court with a bench of several judges. ${ }^{18}$ This model is useful because such judges typically behave with impeccable comity: it is not that they are paragons of courtesy; it is just that their role gives them both resources and incentives to act with courtesy.

\footnotetext{
${ }^{12}$ [2001] 1 All ER 593 per Lord Steyn at 605.

${ }^{13}$ Ibid.

${ }^{14}$ At 606.

${ }^{15}$ At 613 .

${ }^{16}$ At 618 .

${ }^{17}$ At 598.

${ }^{18}$ The basic principles I am seeking to identify would apply to the conduct of trial judges, judges hearing an appeal alone, and to judges in civil law systems.
} 
The comity of judges has two remarkable features, which seem inconsistent. First, the judges do not generally criticise each other. Secondly, the judges disagree with each other. In fact, they disagree freely: appellate judges are free to overrule a decision of a lower court. They are free to take a different view from views expressed by judges in previous cases, although the doctrine of precedent requires them as a matter of law to give effect to the ground of decision in a precedent. And they are free to dissent from each other in the decision of a case. They sometimes say that they hesitate to take a different view from that of another judge, but that is often a way of expressing a special respect for the views of that judge, and even then it never stops them from disagreeing. The mere fact that another judge on the same bench (or the judge of the lower court in an appeal) has taken such-and-such a view is never in itself a reason for any proposition of law. This freedom to disagree, we might say, is actually a responsibility: it would be wrong for a judge to defer to others in forming a view as to the requirements of the law.

The freedom to disagree, and the responsibility to be prepared to disagree, are quite consistent with the judges' practice of not criticizing each other. Of course, trial judges hope not to be overruled, and appellate judges hope to persuade a majority to agree with their reasons. But I think that judges generally do not consider disagreement in itself to imply any form of adverse criticism or condemnation.

Imagine that a dissenting judge said the following:

The majority have misstated the law, which means that they have not fulfilled their judicial obligation to do justice to the parties according to law. They have violated their oaths as judges.

It would be a breach of comity, and it would make the dissenting judge look absurd. But, you might say, what if the dissenting judge's view of the law is right? What if the trial judge and the majority in the Court of Appeal misinterpreted a statute or failed to give a precedent its true import? If that is the case, the trial judge and the majority may have acted in good faith, but they deserve to be criticized for failing to uphold the law and to give effect to the legal rights of the parties. Yet-and here is the point of comity - it is not the place of the dissenting judge to be a gadfly, taking other judges to task. It would be a breach of comity to do so.

Of course, I do not mean that judges are always polite. American legal practice in particular offers many instances of judges showing scorn for other judges. The United States Supreme Court recently held by a majority that the Americans with Disability Act requires the Professional Golf Association to allow a golfer with a circulatory disorder to use a golf cart in its golf championships. In a lively dissent, Justice Scalia wrote that 'The judgment distorts the text of Title III, the structure of the ADA, and common sense. ${ }^{19} \mathrm{He}$ called parts of the majority decision 'quite incredible" ${ }^{20}$, and 'ridiculous" ${ }^{21}$, said that the majority had wrongly asked an 'incredibly silly question' ${ }^{22}$, and concluded by calling parts of the decision 'this Court's Kafkaesque determination... its Alice in Wonderland

${ }^{19}$ PGA Tour, Inc v Martin, 121 SCt 1879, US Or, 2001, decided May 29, 2001 at 1898.

${ }^{20}$ Ibid at 1900.

${ }^{21}$ Ibid at 1904.

${ }^{22}$ Ibid at 1903. 
determination... its Animal Farm determination'. ${ }^{23}$ Was that a breach of comity? It sounds that way to me, but the answer is not obvious: even in that judgment, Justice Scalia claimed to be dissenting "respectfully". ${ }^{24}$ Perhaps legal and judicial culture in America make it possible for judges to maintain respect for each other while criticising each other in terms that would be offensive and insulting in other places. But if it showed disrespect, it was a breach of comity for Justice Scalia to say what he said-even if he claimed to be speaking respectfully, and even if what he said was true.

How could it be a breach of comity to tell the truth? Because comity neither requires agreement on the one hand, nor allows candid criticism on the other. It requires judges to respect each other's role in a system of justice, to support each other (to the extent that they can) in carrying out that role, and to do nothing to interfere with each other's opportunity and ability to carry out that role. It requires what makes it possible for them to work together in a way that promotes the doing of justice according to law. ${ }^{25}$

Suppose that, in the Adan case, the Court of Appeal had held in favour of the British government. Then it would have been possible for the House of Lords to overturn the decision on appeal without for a moment suggesting, even by implication, the view that the judges of the lower court failed to respect fundamental rights and to fulfil their judicial obligation to do justice according to law. If that is possible, then it is also possible for the House of Lords to come to a different interpretation of the Geneva Convention from that of Germany (and to impose it on the British government), without suggesting that the German government and courts or the British government fail to respect fundamental rights, or fail to fulfil their obligations in international law to abide by the Geneva Convention.

We should keep in mind this basic principle of comity: to reject someone's view of the law, and to act on the basis of that rejection is not, in itself, to show disrespect.

\section{Deciding Adan}

So a proper respect for the German authorities does not require a margin of appreciation in the interpretation of the Geneva Convention. It does not require any kind of discretionary latitude of judgment either. Here, the principles of comity - subsidiarity and justiciability - do not require any deference. No considerations of subsidiarity apply, because of the nature of the issues: the question of whether the Geneva Convention must be understood as offering Ms.Adan protection does not in any way depend on Germany's history, practices or legal culture (or, for that matter, on British history, practices or culture). And considerations of justiciability generally do not arise in the interpretation of

\footnotetext{
${ }^{23}$ Ibid at 1905.

${ }^{24}$ Ibid at 1898.

${ }^{25}$ The judicial duty to pursue comity is not absolute: reasons not to work together with persons or institutions are reasons not to pursue comity with them. The judges of a jurisdiction typically do have such reasons because they are part of the same system of justice. The duty of nations to act with comity is much more fragile than the duty of judges, because it is all too common for one nation to have reason not to work together with another nation.
} 
an international convention relating to asylum. Of course, there are many questions about the nature of the threat to Ms.Adan that can best be answered by the government's access to information, both about the political situation in Somalia, and concerning what the German authorities are likely to do. But as those questions relate to the application of the Geneva Convention, they are fully justiciable, and the government can provide the information to which it has special access, in evidence.

So in the interpretation of the Geneva Convention, there was no reason for the House of Lords to defer either to Germany on grounds of subsidiarity, or to the British government on grounds of justiciability. Subsidiarity and justiciability are the central principles of comity, and there was no reason of comity that stood in the way of the decision in Adan.

That does not mean that Germany and France deserve no criticism for adopting the accountability theory, or that the British government deserves no criticism for seeking to send Ms.Adan back to Germany (or for seeking to adopt the accountability theory until the British courts imposed a different interpretation). But it means that it was possible for the House of Lords to decide that she could not lawfully be returned to Germany, without showing a lack of comity toward the German authorities or the British government. That, I propose, is why the judges were right to reject the government's argument about comity with Germany and France. The judges in Adan did not show disrespect for German or French authorities, any more than their decision would have shown disrespect for a judge who dissented.

\section{Conclusion}

From this argument about comity, what general conclusions can we draw concerning the protection of fundamental rights in the twenty-first century? We can conclude that a national court applying multilateral treaties should pay attention to considerations of subsidiarity and justiciability which sometimes require it to defer to the views of other decision makers. But where no such reasons for deference apply, the court should do its best to do justice without hesitating to reach conclusions contrary to those of its own government, or of the governments and courts of other countries. As the House of Lords put it in Adan,

Unanimity on all perplexing problems created by multilateral treaties is unachievable. National courts can only do their best to minimize the disagreements. But ultimately they have no choice but to apply what they consider to be the autonomous meaning. ${ }^{26}$

\footnotetext{
${ }^{26}$ Adan 606, per Lord Steyn.
} 
That is an important point, but I think, with respect, that we might put it even more strongly: a national court should not necessarily even do its best to minimize disagreement - it should only do that where considerations of subsidiarity require it. ${ }^{27}$

It may seem that we can draw a further, important conclusion: if it is not generally the task of a national court to achieve uniformity in the application of multilateral conventions regarding fundamental rights, perhaps nations ought to create a court that can resolve disagreement authoritatively. ${ }^{28}$

That conclusion is attractive, but it should be treated carefully. The mere fact that Germany and France disagree with the United Kingdom does not make the case for an international forum. If some countries take an unjust interpretation of the Geneva Convention, an international tribunal will not improve that situation unless it takes the better approach. I can think of two possible general arguments in favour of such a tribunal: (1) that an international tribunal is more likely to give a just interpretation of a multilateral treaty, or (2) that consistency ought to be pursued regardless of whether the decisions of an international tribunal will be more just than the alternatives. What I have said today does not provide either sort of argument, although it offers part of an argument of the first sort: to the extent that local considerations are irrelevant to the application of instruments for protection of fundamental rights and prejudicial to their interpretation, a carefully designed international court will be more likely to do justice than national courts, because it will be insulated from those local concerns and from the legal culture in which they are treated as significant. And indeed, it seems plausible to say that an international tribunal would be more likely to take the protection theory rather than the accountability theory.

But that is only part of an argument for an international tribunal. Even in the area of asylum law, local considerations are not irrelevant. Whether Ms.Adan is subject to the form of persecution that justifies treating her as a refugee is a question that has nothing to do with Germany. But facts concerning Germany are of great importance to other questions of how the Geneva Convention ought to be applied in Germany. Since murder and kidnapping affect the same fundamental human interests as political persecution, why shouldn't the extremely vague protections of the Geneva Convention be interpreted very creatively, to give refugee rights in Germany to every potential victim of crime in Johannesburg or Los Angeles, or to every victim or potential victim of a civil war? The reasons are facts about the nature of Germany and of the other parties to the Geneva Convention-facts that must be understood in order to know the context in which they signed the Geneva Convention, and therefore in order to give it a true interpretation. Those facts are the facts that justify immigration regulation, and justify national control

\footnotetext{
${ }^{27}$ In any case, the court in Adan could have done little to achieve consistency in the application of the Geneva Convention: if the British courts had deferred to the German interpretation in Adan, they would simply have created an inconsistency between the treatment received by refugees who flee from Somalia to Germany, and the treatment received by refugees who flee to Britain.

${ }^{28}$ Guy Goodwin-Gill discusses the need for an international authority to achieve consistent interpretation of the Geneva Convention in 'The Margin of Appreciation: Different or Disparate?' (1999) 11 International Journal of Refugee Law 730 [commenting on the Court of Appeal decision in Adan].
} 
over that regulation. Those facts are reasons why the parties to the Geneva Convention agreed to give rights to refugees, and did not simply agree to a universal right of establishment. A court insulated from the special concerns and the legal culture of a country will be free from some distracting influences, but it will also be distanced from some genuine concerns that are very relevant to the justice or injustice of awarding refugee status. The insulation of an international tribunal would unequivocally count in favour of such a tribunal (as it counts in favour of international tribunals for, e.g., crimes of genocide), if determinations of refugee status had nothing to do with the interests and conditions of the country in which asylum is sought. Since that is not the case, the argument for an international tribunal needs to show not only that such a body would be better insulated from irrelevant local considerations, but also that, in interpreting the Geneva Convention, it would pay attention to the interests of the country to which an asylum seeker flees, and that it would not succumb to the temptation to extend the Convention's protections irresponsibly. To accept the jurisdiction of an international tribunal to determine refugee status would be to give control over large parts of asylum law to an independent authority which could be expected to act creatively and perhaps dramatically. For any European lawyer to see that, it is enough to think for a moment of the way in which the European Court of Justice has developed European Union law, or to think of the way in which the European Court of Human Rights has developed the law of the European Convention on Human Rights.

What of the second argument: that consistency ought to be pursued regardless of justice? There is one good reason for consistency: to avoid the 'forum shopping' that results when asylum seekers look around for a jurisdiction with a favourable policy. But that can never be a reason that operates regardless of justice. If one jurisdiction acts unjustly, the only appropriate solution to the resulting problem of forum shopping is to remove the injustice. If one jurisdiction gives applicants an excessively favourable reception, the solution is for that jurisdiction either to accept the resulting influx of forum-shoppers, or to impose just restrictions. Either way, forum shopping does not give reasons for an international tribunal.

Yet there is a certain attraction to the idea of consistency. Imagine a hypothetical situation: suppose that Britain sometimes acted on the protection theory and sometimes on the accountability theory. The problem would not only be the injustice in the cases in which it acted on the protection theory, you might say; an additional problem would be that the British legal system would not be able to give a justification for its approach that explained the different outcomes. It would not be treating like cases alike.

The value of treating like cases alike is apt to be exaggerated (after all, in the case we have imagined, the only way to improve matters would be to start treating all cases justly). But the point I want to emphasize is that the inconsistency would only be a problem of any kind because of the nature of the British legal system: its character as the system of standards for public life in a community which aspires to act as one nation.

And then the question of whether there ought to be a single tribunal deciding cases in the United Kingdom and Germany is, partly, a question of whether the United Kingdom and Germany ought to be part of one system, and if so in what sense. And that, of course, involves the general question of the extent to which different nations ought to act as one, and the particular question of the appropriate nature of the European Union. 
For its part, the British government can see the value of acting in concert with Germany or France, but it has given effect to that value in the wrong way. Britain is not pressing for an international tribunal to determine refugee status. Instead (in response to the Court of Appeal decision in Adan), the British Parliament enacted a provision deeming a member state of the European Union to be a safe third country, regardless of the way in which it interprets the Geneva Convention. ${ }^{29}$ So the good effect of the Adan decision has been stripped from future asylum seekers who come from another European Union country. The government has chosen to solve the forum-shopping problem, at the price of justice.

That action is a reminder that acting with comity is a duty for the executive and the legislature, and not only for the courts. Politicians are not necessarily worse at it than judges, but from politicians it requires statesmanship. Removing an embarrassment from an ally is bound to be gratifying to the ally. But it is not necessarily an act of comity. And applying the Geneva Convention justly, in accordance with its terms, could never show a lack of comity - no matter who disagrees.

${ }^{29}$ Immigration and Asylum Act 1999, c.33 s.11. 